\title{
Hartwig przestrzennie
}

\section{Recenzja książki Elżbiety Dutki Centra, prowincje, zaułki. Twórczość Julii Hartwig jako auto/bio/geo/grafia, Towarzystwo Autorów i Wydawców Prac Naukowych „Universitas”, Kraków 2016}

Geopoetyka, przynajmniej na aktualnym etapie, nie jest teorią, ale przede wszystkim praktyką badawczą $[\ldots]^{1}$.

Ten ścisły związek pomiędzy gestem pisarskim, literacką poiesis, a materialnością miejsca dowodzi, iż miejsce i literatura potrzebują się wzajemnie: przestrzeń wydrążona z pamięci odzyskuje swą historię i przeszłość (nawet jeśli ma ona niekiedy status na poły wyobrażeniowy), literatura z kolei zyskuje zakotwiczenie w materii, będącej śladem przeszłości² ${ }^{2}$.

Elżbieta Rybicka

Pisanie o poetce tak szeroko rozpoznanej, interpretowanej i komentowanej wymaga nie lada odwagi, oryginalnego zamysłu badawczego i przede wszystkim czytelniczej fascynacji względem poezji. Do tego wniosku dochodzi Elżbieta Dutka, która na samym początku swojej pracy ${ }^{3}$ pisze o naukowej recepcji twórczości autorki Wierszy amerykańskich, by móc zaproponować własne, nowe odczytanie. Julię Hartwig poznajemy jednak nie tylko jako autorkę tomów poetyckich, ale - do czego badaczka nawiązuje w kolejnych częściach swojej książki - także jako wrażliwą i dociekliwą miłośniczkę

* Uniwersytet im. Adama Mickiewicza w Poznaniu, Wydział Filologii Polskiej i Klasycznej, Instytut Filologii Polskiej, Zakład Badań nad Tradycją Europejską, e-mail: egalcz@gmail.com.

1 E. Rybicka, Geopoetyka. Przestrzeń i miejsce we wspótczesnych teoriach i praktykach literackich, Kraków 2014, s. 12.

2 Tamże, s. 313.

3 E. Dutka, Centra, prowincje, zaułki. Twórczość Julii Hartwig jako auto/bio/geo/grafia, Kraków 2016. W artykule cytaty z niniejszego wydania zostały opatrzone numerem strony w nawiasie. 
literatury. Już na tym etapie budowana jest paralela między zainteresowaniami biograficznymi poetki a sposobem ujmowania jej dzieł przez autorkę książki. Tytuł rozprawy naukowej kumuluje napotykane przez czytelnika rozgałęzienia - epicentrum badawcze stanowią życie i twórczość w kontekście przestrzennym. Książka jest kontynuacją zamiłowań naukowych Dutki „,zlokalizowanych” wokół tematyki spacjalnej oraz biograficznej4.

Auto/bio/geo/grafia to formuła, która wyrasta z założeń geopoetyckich. Inspirująca i w ostatnich latach szeroko opracowywana teoretycznie ${ }^{5}$ praktyka badawcza zostaje urozmaicona i spotęgowana w nowej odsłonie. Autobiografizm implikowany (m.in. sygnały zakodowane w tekście - relacja między tekstami) oraz strategia autobiograficzna (sygnały zewnątrztekstowe: $n p$. wywiady, pamiętniki) są zestawione z kategorią spacjalną. Życie Hartwig staje się tekstem, dopełnionym przez utwór poetycki: „Zatem nie tyle poetka stawia znak równości między życiem a pisaniem, ile poszerza życie o wiersz" (s. 16).

W kolejnych rozdziałach przyglądamy się wierszom, ale także i innym formom aktywności literackiej. Zostają one przypisane do tytułowego centrum, prowincji i zaułka. Obrana nomenklatura jednocześnie odzwierciedla okresy życia we Francji, Ameryce i Polsce. Co ważne: „Dla auto/bio/geo/grafii bowiem charakterystyczne jest odejście od linearnego, wyznaczanego przez chronologię porządku na rzecz odniesień przestrzennych" (s. 31). Wspomniane odniesienia przestrzenne funkcjonują jako klucz kompozycyjny książki podzielonej na trzy segmenty: Francja - nostalgiczne centrum, Ameryka prowincja codzienności oraz Polska - zaułki historii i pamięci, w ramach których, w konkretnych przykładach utworów, każdorazowo zostają zauważone spacja i łączące się z nią przemiany.

Należy podkreślić, że badaczka powołuje się na pojęcie auto/bio/geo/grafii stworzone przez Elżbietę Rybicką. Nie bez powodu używam słowa pojęcie (dodałabym wędrujące - odwołując się do książki Mieke Bal ${ }^{6}$ ) - zamiast termin, jak czyni to Dutka. Poszczególne, baczne przyglądanie się zgromadzonym tekstom nigdy nie jest domknięte. Stanowi kolejną próbę zrozumienia, nienarzucającą odczytania ostatecznego: „Trajektoria auto/biograficzna jest bowiem współwyznaczana przez akty deterytorializacji i reterytorializacji, kolejne punkty na trasie to nie tylko miejsca postoju, ale miejsca doświadczenia

4 Mowa o takich książkach jak: Ukraina w twórczości Włodzimierza Odojewskiego i Włodzimierza Paźniewskiego, Katowice 2000; Okolice nie tylko geograficzne. O twórczości Andrzeja Kuśniewicza, Katowice 2008; Zapisywanie miejsca. Szkice o Slasku w literaturze przełomu wieków XX i XXI, Katowice 2011; Próby topograficzne. Miejsca i krajobrazy w literaturze polskiej XX i XXI wieku, Katowice 2014.

5 Warto wspomnieć o takich pozycjach jak m.in.: A. Kronenberg, Geopoetyka: związki literatury i środowiska, Łódź 2014; Przestrzenie geo(bio)graficzne w literaturze, pod red. E. Konończuk i E. Sidoruk, Białystok 2015; Przestrzeń - literatura - doświadczenie: z inspiracji geopoetyki, pod red. T. Gęsiny i Z. Kadłubka, Katowice 2016; Geograficzne przestrzenie utekstowione, pod red. B. Karwowskiej, E. Konończuk, E. Sidoruk, E. Wampuszyc, Białystok 2017.

$6 \mathrm{M}$. Bal, Wędrujace pojęcia w naukach humanistycznych. Krótki przewodnik, przeł. M. Bucholc, Warszawa 2012. 
granicznego lub pogranicznego [...], które przenoszone są dalej pod postacią śladów pamięciowych, pamięci ciała, języka, obrazów"7"

Rozdział pierwszy poświęcony został debiutanckiemu tomowi Pożegnanie oraz ostatniemu "francuskiemu" cyklowi wierszy zawartemu w Podziękowaniu za gościnę, w którym czytelnik poznaje Paryż lat czterdziestych ubiegłego stulecia. Dutka w wierszach dostrzega zakodowane lektury poetki - w tamtym czasie zaznajamiała się ona ze stolicą Francji za pośrednictwem dzieł Guillauméa Apollinairéa czy Gérarda de Nervala. Zawarte $\mathrm{w}$ utworach wątki dotyczące pamięci i pamiętania nie są związane jedynie z prywatnymi wydarzeniami z życia Hartwig, ale także nawiązują do szeroko rozumianej historii Europy i jej kultury, przeżyć związanych z okresem II wojny światowej. Dlatego mylnie byłoby spodziewać się w tym rozdziale sentymentalnej interpretacji wierszy z lat młodości. Badaczka szuka dalej, nie tylko $\mathrm{w}$ centrum poetyckim, ale także $\mathrm{w}$ tekstach znajdujących się na obrzeżach. Poznajemy utwory korespondujące, poszerzające możliwości krytycznego myślenia, dzięki którym Hartwig ukazuje nam się jako biografka.

Najciekawszym fragmentem pierwszego rozdziału wydaje się jego ostatnia, czwarta część Paryż, Musée de l'Orangerie - „wizualne zaszczepienie". Tytułowa metafora została zaproponowana przez Adama Dziadka. Szkoda, że Dutka w tym momencie nie pokusiła się o stworzenie własnej formuły, gdyż świetnie wędruje między dziedziną literatury i malarstwa - próbując doszukać się $\mathrm{w}$ twórczości poetki miejsc wspólnych. Za pośrednictwem słów Hartwig przyglądamy się obrazom Marca Chagalla, Pietera Bruegla, Leonarda da Vinci, Salvadora Dali, wspomniani zostają także, jak zauważa badaczka, mniej znani malarze: Robert Campin, John James Audubon.

Poza literaturą malarstwo jest dla poetki najbliższą dziedziną sztuki. We fragmentach dziennika czytamy jej interpretacje obrazów, przemyślenia oraz zapisy rozmów z malarzami. Przestrzeń muzeum to kolejna rozczytywana przez Dutkę spacja twórczej inspiracji, ale także pamięci, bycia blisko autora obrazu: „W pisarstwie Hartwig ramy obrazu są granicą nieustannie przekraczaną. Osoba mówiąca «wchodzi» w obraz, ale i często widoczny jest ruch $\mathrm{w}$ odwrotnym kierunku - to, co namalowane, wykracza poza ramy w stronę konkretnej biografii [...]" (s. 88). Badaczka nie pomija wcześniejszych prac naukowych, które podejmowały kwestie interdyscyplinarne oraz kulturowe w poezji Hartwig. Częste odwoływanie się do innych tekstów krytycznych (m.in. Anety Grodeckiej, Marcina Telickiego, Marty Flakowicz-Szczyrby) odnajdziemy we wszystkich fragmentach książki. Nawiązania jednak zawsze są przemyślane, nie zaburzają oryginalnego wywodu opartego na tytułowym pojęciu, funkcjonują jako tło i dopełnienie.

W drugim rozdziale znajdujemy się w Ameryce, która jest przefiltrowana przez naukową i poetycką osobowość Hartwig. Sposób pisania o kolejnej przestrzeni pozostaje taki sam jak w poprzedniej części książki. Przewodnikami po nowym świecie są Emily Dickinson, Edward Hopper oraz William

7 E. Rybicka, dz. cyt., s. 289. 
Carlos Williams. Nie brakuje także polskich powiązań, a szczególnie zostaje zaznaczona relacja z Czesławem Miłoszem oraz wpływ, jaki wywarł na poetkę utwór Widzenia nad Zatoką San Francisco. Dutka próbowała wcześniej ukazać „mit Francji”, na którym także wychowała się Hartwig, znaleźć jego źródła oraz skutki zmaterializowane w słowie poetyckim i obrazie malarskim. Tym razem kraj nieograniczonych możliwości - Ameryka - jawi się jako „wyspa samotności”; na niej autorka Dziennika amerykańskiego próbuje stworzyć własną przestrzeń życia, funkcjonowania w codzienności.

Tak jak wszystkie tytuły i podtytuły łączą się z geograficzną praktyką interpretacji, tak i tutaj zostaje zauważona przestrzeń Nowego Jorku, Amherst, ale i oczywiście Museum of Modern Art. Poetka nie czuje się w Ameryce tak dobrze jak na starym kontynencie, we Francji. Szuka kontaktu z nową przestrzenią, jednak sztuka wydaje się tym razem niewystarczająca. W piątym podrozdziale zatytułowanym Nad Pacyfikiem i w górach Sierra Nevada - zwykła mistyka Dutka zwraca uwagę na fascynację naturą, która pozwoliła poetce na metaforyczne wyjście $\mathrm{z}$ muzeum i kontemplację teraźniejszości. W ten sposób odnajduje się ona w nowym kontekście. Na początku napotykamy słowa Hartwig z rozmowy przeprowadzonej przez Artura Cieślara, opublikowanej w książce Życie to podróż, to ocean ${ }^{8}$ :

Nigdy wcześniej nie sądziłam, że można objąć wzrokiem tak szeroki
horyzont, że można się znaleźć tak daleko od siedzib ludzkich, na praw-
dziwych pustkowiach, w niesamowitych przestrzeniach, niemożliwych do
objęcia wzrokiem ani rozumem. Do dziś mam przed oczami te wciąż inne
horyzonty gór, Wielki Kanion, pustynie. Kiedy znajdziemy się oko w oko
z naturą, wszystko inne wydaje się mało znaczące (podkr. - E.D.) (s. 148).

Naturę zestawia się z kulturą i równocześnie przypisane zostają im przestrzenie: otwarta i zamknięta. Co ważne, w tekście badawczym ani w poezji nie wykluczają się one, obie spacje łączą się w biografii - nie wchodzą w korelacje, współistnieją osobno na zasadzie „otwartej symbiozy”. Inną ważną kwestią są sprawy somatyczne. Cielesność, która odgrywa ogromną rolę w praktyce geopoetyckiej, staje się jedyną możliwością "dosięgnięcia” horyzontu, zauważenia go i zapamiętania. Zmysł wzroku, dominujący również w recepcji sztuki plastycznej, ukierunkowuje odczucia wewnętrzne, które są często impulsem do tworzenia tekstów literackich.

Inny zauważony wątek to podróż, pozwalająca oswajać samotność i ją akceptować oraz czerpać z niej przyjemność oraz korzyści. Bycie w pojedynkę wywołuje także pytanie o Boga i przeznaczenie. Wybrana formuła auto/bio/ geo/grafii jako praktyka stanowi zawsze dopełnienie tekstu literackiego, który to wyznacza kierunek interpretacji. Autorka książki zauważa, że właśnie pobyt w Ameryce jest momentem przemian na gruncie poetyki:

8 Życie to podróż, to ocean. Z J. Hartwig rozmawia A. Cieślar, Poznań 2014, s. 60-61, cyt. za: E. Dutka, Centra, prowincje, zautki, s. 148. 
Pod wpływem doświadczeń amerykańskich nastąpiło zmodernizowanie idiomu poetyckiego tej artystki, uproszczeniu ulega styl, częściej pojawia się język potoczny, wzrasta znaczenie codzienności i pospolitych doświadczeń (s. 151).

Poza badawczą kontemplacją konkretnego utworu Dutka dąży do stworzenia szerszego obrazu twórczości, do zauważenia zmian fundamentalnych, kształtujących artystyczną świadomość:

„Kraj bez snów” okazuje się zarazem „szerokim horyzontem”, otwierającym na to, co przekracza wydawałoby się tak bardzo „twardą” rzeczywistość najbardziej nowoczesnej, stechnicyzowanej cywilizacji. Po wielu latach różnych artystycznych poszukiwań poetka znalazła własną formę zapisu tego typu doświadczeń. „Zwykła” mistyka wypełnia „błyski” utwory, które stały się wręcz znakiem rozpoznawczym późnej twórczości Julii Hartwig (s. 156).

Ostatnia część książki Polska - zaułki historii i pamięci staje się okazją, aby powrócić do przeszłości. Podróż tutaj jest symboliczna, a kontakt z krajem ojczystym skomplikowany i nieoczywisty. „Zebrane” w książce przestrzenie lat dzieciństwa i młodości oraz wspomnień, także tych późniejszych, to Lubelszczyzna, Kielecczyzna, Warszawa i Lublin. Osobną spacją są opisane relacje Hartwig z polityką i historią oraz fotografią. Omawiane utwory pochodzą z tomu Wybór wierszy poetów lubelskich oraz zbioru reportaży Z niedalekich podróży. W poprzednich rozdziałach przestrzenie łączyły się z prywatnymi zainteresowaniami poetki i jej biografią. Polska zostaje utożsamiona ze wspólnotą pamięciową, wspomnienia jednostki reprezentują świadomość zbiorową. Także w tej części powracają pytania dotyczące sposobu opisania Zagłady, m.in. w utworze Ziemia dawnego getta w Warszawie nie chce się zielenić.

Książka Dutki jest interesującą i oryginalną próbą odczytania na nowo twórczości poetki rozpoznanej i cenionej. Zupełnie inaczej więc odbieramy znane utwory, których drobiazgowa analiza dąży jednak do zbudowania solidnej konstelacji - od szczegółu do syntezy. Tytułowa formuła auto/bio/ geo/grafii, tak jak w założeniach geopoetyckich, jest praktyką w działaniu, impulsem do badania literatury pod kątem przestrzennym i biograficznym. W książce staje się stelażem rozważań, uzupełnionym umiejętnie dobraną literaturą przedmiotu. Hartwig odczytujemy wielowymiarowo i interdyscyplinarnie, będąc jednak zawsze u źródeł tekstu wyjściowego to znaczy poezji, która "dzieje się" przestrzennie i skierowana jest we wszystkie strony. 


\section{B I B L I O G R A F I A}

Bal M., Wędrujące pojęcia w naukach humanistycznych. Krótki przewodnik, przeł. M. Bucholc, Warszawa 2012.

Dutka E., Okolice nie tylko geograficzne. O twórczości Andrzeja Kuśniewicza, Katowice 2008.

Dutka E., Próby topograficzne. Miejsca i krajobrazy w literaturze polskiej XX i XXI wieku, Katowice 2014.

Dutka E., Ukraina w twórczości Włodzimierza Odojewskiego i Włodzimierza Paźniewskiego. Katowice 2000.

Dutka E., Zapisywanie miejsca. Szkice o Ślasku w literaturze przełomu wieków XX i XXI, Katowice 2011.

Geograficzne przestrzenie utekstowione, pod red. B. Karwowskiej, E. Konończuk, E. Sidoruk, E. Wampuszyc, Białystok 2017.

Kronenberg A., Geopoetyka: związki literatury i środowiska, Łódź 2014.

Przestrzenie geo(bio)graficzne w literaturze, pod red. E. Konończuk i E. Sidoruk, Białystok 2015.

Przestrzeń - literatura - doświadczenie: z inspiracji geopoetyki, pod red. T. Gęsiny i Z. Kadłubka, Katowice 2016.

Rybicka E., Geopoetyka. Przestrzeń i miejsce we wspótczesnych teoriach i praktykach literackich, Kraków 2014.

\section{STRESZCZENIE}

Auto/bio/geo/grafia jest twórczą i niebanalną soczewką interpretacyjną autorki książki, która przygląda się poszczególnym tomom, wierszom i tekstom o sztuce autorstwa Julii Hartwig. Ramą kompozycyjną, która pozwala na prowadzenie płynnej narracji, staje się przestrzeń, przypisana do tytułowego centrum, prowincji i zaułka. Wspomniane odniesienia przestrzenne funkcjonują jako klucz kompozycyjny książki podzielonej na trzy segmenty: Francja - nostalgiczne centrum, Ameryka - prowincja codzienności oraz Polska - zaułki historii i pamięci, w ramach których, w konkretnych przykładach utworów, każdorazowo zostaje zauważona spacja i łączące się z nią przemiany.

\section{Słowa kluczowe}

Julia Hartwig, geografia, biografia, geopoetyka 


\section{S U M M A RY}

\section{Hartwig spatially}

A review of the book by Elżbieta Dutka Centra, prowincje, zaułki. Twórczość Julii Hartwig jako auto/bio/geo/grafia, Towarzystwo Autorów i Wydawców Prac Naukowych “Universitas”, Kraków 2016

Auto/bio/geo/graphics forms a creative and original interpretive lens of the author of the book, which looks at individual volumes, poems and texts about art by Julia Hartwig. Space assigned to the eponymous center, province and backstreets becomes the compositional frame, allowing for a smooth narration. These spatial references function as the compositional key of the book divided into three segments: France - a nostalgic center, America - the everyday life province and Poland - backstreets of history and memory, in which, in specific examples of works, each time a space and its transformations are accounted for.

\section{Keywords}

Julia Hartwig, geography, biography, geopoetics 